\title{
Audience Power in the Production of Talent-Show Stars: China as an Example
}

\author{
Li Cuia
}

\begin{abstract}
In China, all types of stars coexist in the country's star system: party stars, commercialized stars, and talent-show stars, which influence diverse type audience and have diverse implications. Based on Couldry's framework (2000) of media power, through in-depth interviews with media professionals, this study compares the creation of party stars, commercial stars, and talent-show stars as represented by Li Yuchun. Data show that there was few audience power involved into the production of party stars and commercialized stars. Rather, there was media power involved into the production of party stars and commercialized stars. Meanwhile, this study argues that there was audience-power influence on Li Yuchun's rise to stardom, and it provides some details about the manipulations of media institutions that were involved in the creation of this pop star. However, it is difficult to prove that audience power is the main influence on Li's stardom. The implications of her stardom and this production process on China's star system and China's state power are also discussed in this study.
\end{abstract}

\section{Keywords}

Talent show, stardom, audience power, media power, Chinese popular culture

In China, all types of stars coexist in the country's star system: party stars, commercialized stars, and talent-show stars. "Party stars" refers to those stars who are the propaganda tools of party ideology and who attain personal reputation and receive economic returns at the same time ${ }^{1}$. Talent-show stars from Super Girls' Voice (SGV) have been popular, including Li Yuchun, who was the champion on SGV in 2005. In 2010, Li was the top earner among mainland female singers (Forbes 2010).

The talent show, SGV, launched by the Hunan Provincial Television Station (HNTV) in 2005, was regarded as a successful model for creating stars from ordinary people (Sun and Zhang 2005; Hou 2005). However, with regard to the production of their stardom, more details are needed besides the texts of the shows themselves: Particularly, details about the production of the show and the influence of various agencies after the show were no longer produced. Unfortunately, there is a lack of scholarship on this issue. In addition to this, the application of related exploration in Pop Idol (Holmes 2004) to the Chinese media context is questionable.

This study explores the stardom of Li Yuchun to address the production of stars from $S G V$, because she was the champion of the show in 2005, and attracted the majority of media attention and audience votes, and therefore, she is a good subject for the study of audience power (Meng 2009).

Since there was negotiation and the reproduction

aSouthwest University, China

\section{Correspondent Author:}

Li Cui, School of Journalism and Communication, Southwest University, Beibei, Chongqing, China

E-mail: cloudhk22@gmail.com 
of symbolic media power in the show (Cui and Lee 2010), it is hard to accurately evaluate the true status and position of $\mathrm{Li}$ Yuchun, and what she represents in the media world, without exploring media power. Thus, Couldry's (2000) framework of media power is appropriate for this study. In this study, the production of other stars made in traditional ways in China's music industry will also be discussed by using Couldry's framework (2000).

\section{MEDIA POWER ISSUES AND DIVERSE APPROACHES}

This study attempts to address the production of $\mathrm{Li}$ Yuchun's stardom in the view of media power. For media effects researches, media power is thus seen as the influences of media use on the audience's attitudes and activities, individually or collectively (Feilitzen 1994; Katz and Lazarsfeld 1955; McCombs and Shaw 1972; Ball-Rokeach and DeFleur 1976). However, this behavioral approach fails to explain the complexity of the exercise of power (Feilitzen 1994; Gerberner 1994). The ignoring of interests and struggles of diverse social groups by the media effect approach was remedied by the political economy approach (Murdock 1988; Garnham 1990; Murdock and Golding 1974), but this approach possibly ignores the power of media institutions themselves and audience' subjectivity (Coudlry and Curran 2003). The third approach is to consider media power as a kind of social power, and emphasizes the importance of the representational power of media. This approach is grounded in the concept of symbolic power in sociology (Bourdieu 1991) and emphasizing symbolic media power.

\section{Symbolic Media Power}

Symbolic media power refers to the power of the media to naturalize ideology, or the social order (Hall 1988). This approach views media power as a kind of social power, with its own independence and subjectivity (Couldry and Curran 2003; Hall 1988). This study adopts Couldry's (2000) framework in this approach as its theoretical framework. Couldry tends to view the media as a social process which is able to influence audiences and change their views in "watching the world" (2000). In the manipulation of reality by media, there are naming, framing, and ordering involved in the exercise media power (2000). The two facets of media power: Naming and framing are what many media sociologists have long pointed toward (Gitlin 1980).

But the most original part of Couldry's analysis is the discussion on ordering (Cui and Lee 2010). For Couldry, ordering refers to the construction and reproduction of a division between the media world and the everyday life world (2000). The former is seen as glamorous and extraordinary, while the everyday world is mundane (Couldry 2000). This media/ordinary distinction is reproduced as legitimate, and is a main tool for maintaining symbolic media power.

Nevertheless, the distinction between the media and ordinary worlds is not stable. The trespassing of this boundary between the two worlds can be a particularly interesting experience for ordinary people, although it usually ends up with the legitimization of the boundary (Couldry 2000). To contest this symbolic power, the possibilities lie not only in the new production or distribution of media products, but also in the new ways of media consumption (Couldry 2003). Couldry's framework has explanatory power for people from the two diverse worlds meeting each other, such as celebrities showing up on some reality TV program (2000). That is why this study use Couldry's framework (2000).

\section{STARDOM}

Beside with regarding stars as half-open texts (Dyer 1998; Ellis 1992; Zhang and $\mathrm{Hu}$ 2011), or as commodities even industries (Gamson 1994; Gamson 
2001; Chen 2007), stars also could be viewed as a media process or "cultural formation" (Turner 2004: 9). In this view, stars are seen as concentrations of media's symbolic power (Litter 2004; Couldry 2000), which adopted by this study, because it permit explorations on the production stars from a perspective of media power.

Among stardom studies, explorations on "star quality" occupy most of the relevant coverage of the issue. Ordinariness and extraordinariness are contradictive, and yet co-exist in the construction of stardom (Dyer 1998; Ellis 1992; Darling-Wolf 2004). In 1920s and 1930s, the construction of Hollywood stardom was mainly dependent on the specialness (Dyer 1998; Gamson 1994). Currently, reality TV is more likely to construct stardom for its contestants—ordinary people, mostly by emphasizing their realness and ordinariness (Holmes 2004; Reijnders, Rooijakkers, and Zoonen 2007). Besides the emphasis on ordinariness, the original part of current production of stars in talent shows is the emphasis on the production process of stardom for the audience, which brings about closeness and intimacy between audience and contestants, the would-be stars (Holmes 2004).

Thus, there are debates on whether the rising importance of ordinariness and intimacy in reality TV or other genres might imply the deconstruction of traditional stardom, and even the democratization of fame (Gamson 2001; Turner 2006; Turner 2004; Holmes 2004; Reijnders et al. 2007). This situation reminds us the necessaries of related explorations on talent show stars.

\section{FANS}

A special group of a star's audience consists of his/her fans. Fans are always viewed as a deviant audience, as they constitute a special group addicted to some texts (Pullen 2004; Grossberg 1992). However, Fiske and other scholars contend that fans are active consumers more than an obsessive audience and that they are actively involved in cultural production and stardom (Fiske 1992). Fans' consumption is not blind, and it continues to attract the attention of the entertainment industry (Pullen 2004). For example, Li Yuchun's fans made a great contribution to her album sales and concerts as she rose from SGV (Zhang 2007). Although there are diverse opinions on the political potential of fans (Zoonen 2009; Fung 2009; Jones 2003), when considering a new fan culture created by their participation in talent shows (Keane, Fung, and Moran 2007), it might be timely to evaluate the effects of fandom on stardom rather than focusing on stars' influence on fans, particularly in the case of $\mathrm{Li}$ Yuchun.

\section{EE-MEDIA: AN AGENT COMPANY BEHIND LI YUCHUN AND SUPER GIRLS}

Li Yuchun and other contestants on $S G V$, which are called as Super Girls, attained their fame from the show, which can be categorized as a talent show: one of subgenres of "reality TV". Similar to other media phenomena, the rise of reality TV can be examined by focusing on the genre's commercial imperatives (Fairchild 2007), technological applications (Andrejevic 2004), textual politics (Bell-Jordan 2008), and audience reception (Hartley 2004). As some studies have indicated, the rise of talent shows such as $S G V$ in China has its roots in the changing political economy of Chinese media (Cui and Lee 2010). However, a political economy analysis of SGV cannot offer a comprehensive view of the stardom of $\mathrm{Li}$ Yuchun or other Super Girls. Hence, we turn to agencies that represented Li Yuchun and other Super Girls-EE-Media (tianyu gongsi)—and try to find clues regarding Li Yuchun's stardom and star production.

Li Yuchun and the nine other Super Girls who entered the national finals of $S G V$ signed with the agent company EE-Media. However, EE-Media's 
chaotic management, its limited experience and resources might not have positively influenced their career development.

The first problem at EE-Media was the chaos in its management. Only 10 months after the establishment of EE-Media (in 2004), its financial problems led to the withdrawal of the only private capital from the Hong Kong investor with agency experiences (35\% of stock) (Jiang and Wang 2009; Wang 2009). Thus, the property rights of EE-Media were transferred to a totally state-owned subsidiary of HNTV (Wang 2009). EE-Media's dependence on HNTV, and their limited experience as an agency for artists, put forth unclear aims and unprofessional strategies in the star production of signed talents. For example, EE-Media turned from the promotion of artists individually to the promotion of SGV and "Super Girls" collectively, and then back again, several times from 2004 to 2009 (Fan 2005; Jin 2006; Wang 2009), just because promoting all Super Girls together benefited HNTV more than it did EE-Media.

Furthermore, although HNTV's market share was not small ${ }^{2}$, the State Administration of Radio, Film, and Television (SARFT) issued many restrictions on the timing, procedures, judges, and airing of entertainment shows from 2007 (Xinhua Net 2007), which limited the number of audience members and limited the audience's emotional investment in HNTV's talent shows from which the new talents of EE-Media are produced.

EE-Media tried to integrate their resources with outside resources that had experience in creating films and television dramas (Jiang and Wang 2009) and attempted to focus on their own artists, particularly $\mathrm{Li}$ Yuchun, their top earner. However, it is difficult to conclude that EE-Media could guarantee stable career development for other new talents. Meanwhile, new competitors with overseas capital and media-producing experience, such as the producer of the Voice of China (zhongguo haoshengyin) ${ }^{3}$, Pal Edward Culture and Communication Company (canxing zhizuo) which is controlled by News Cooperation, are making EE-Media's future uncertain.

\section{CO-EXISTENCE OF DIVERSE STARS IN CHINA'S MUSIC INDUSTRY AND POWER RELATIONSHIP}

In China, after 1978, the introduction of Deng's economic reforms and open-door policy in 1978 allowed for the transmission of celebrities from Hong Kong and Taiwan. In order to respond to the influence of Hong Kong and Taiwan music styles, the government started to develop state-run popular music in the middle of the 1980s (Jones 1994), which spurred local pop stars such as Mao A'min, and Liu Huan in mainland China (Chen 2011; Baranovitch 2003). The party-state also produced party stars, such as Dong Wenhua ${ }^{4}$, as propaganda tools to resist the influence of outsiders.

After 1989, with the marketization reform and the weakening of ideological control on cultural production and consumption (Baranovitch 2003; Saich 1994; Jones 1994), non-state capital entered into music production and circulation and spurred the emergence of market-oriented recording companies, the maturity of the commercial show market and commercialized stars (Jin 2002), such as Yang Yuying.

From the late 1990s into the early twenty-first century, the disarray of copyright law in mainland China and the decline in the profits of recording companies lead to lack of new components in the star system, which left possible spaces for stars from talent shows. The fame of Li Yuchun and other stars from talent shows might represent another kind of stars: talent show stars.

Currently, there is a co-existence of all kinds of stars in the star system. Party stars mainly depend on state power which always negotiates with media power. For example, state-sponsored galas and concerts often limit the proportion of party stars on 
stage (Dahebao 2002), because of the younger generation with few interests on the party ideology (Fung 2009).

Commercial stars mainly rely on media power, but they also have to conform to state power, such as their partial cooperation with the party-state in return for media resources (Baranovitch 2003). Talent-show stars can be divided into those who emerged prior to the voting procedure change in September 2007 (prohibition of audience voting in shows) and those who emerged after this change (Xinhua Net 2007). The former, such as Li Yuchun, are products of both media power and audience power, whereas the latter are the products of negotiation and rebalance of media power and state power.

\section{METHODOLOGY}

This study uses in-depth interviews to examine the production of Li Yuchun's stardom, because it is helpful to explore some of the problems inherent in the perceptions of people and their experiences (Minichiello et al. 1995).

For this purpose, the author interviewed entertainment journalists, producers, and directors, because they closely follow entertainment reports and are familiar with the current popularity of stars and various production details. The author interviewed four entertainment journalists from two major metropolitan dailies in Chongqing, a producer, and a director at HNTV in Changsha. The choice of Chongqing was not only related to the author's social connections there but also because Chongqing is a city in which $S G V$ was popular in 2005. The choice of interviewing people in Changsha was because HNTV was the producer of $S G V$ and it still has a close relationship with $\mathrm{Li}$ Yuchun's agent company, EE-Media. The producer is presently a producer of a game show on HNTV, and the director is the current executive chief director of Happy Girls' Voice (HGV), the revised version of $S G V$ produced in 2009 and 2010, and is also the producer of Happy Boys' Voice (HBV), a boy version of Happy Girls' Voice produced in 2007. This director also directed a $\mathrm{Li}$ Yuchun concert in Nanjing in 2009. In addition to interviews, the author also did field work in HNTV, including observing the recording of the entertainment shows and discussions with studio audiences and staff.

Given the schedules of journalists, three interviews were carried out by telephone, each lasting approximately 30 minutes, and another interview was conducted by MSN. The interviews with the producer and director were face-to-face interviews, and each lasted about one hour. The interviews in Chongqing began in August, 2010, and ended in late August of the same year, and the work at HNTV started in the middle of September, 2010, and finished in late September, 2010.

\section{THE PRODUCTION OF PARTY STARS}

The production of party stars involves two correlated types of places: colleges that provide the professional vocal training for singers and the song and dance troupes of the People's Liberation Army (PLA) that offer jobs and platforms on which to perform. Each type of place has its particular function in the production process of party stars. Most party stars come from one of two colleges: either the China Conservatory or the PLA Academy of $\mathrm{Arts}^{5}$, because the China Conservatory is the only institution which focuses on education in Chinese folk music and traditional music in $\mathrm{China}^{6}$, and many patriotic songs and revolutionary songs are written in the style of folk music (Baranovitch 2003). While the PLA Academy of Arts is the only institution providing art education in the PLA, which means its students are the main choices for the military song and dance troupes.

These two institutions monopolize good musical training for prospective party stars and, more importantly, offer social relationships for students. 
Most party stars in the 1980s and the early 1990s were students of well-known teachers. For instance, Peng Liyuan and Song Zuying are students of Jin Tielin. While in the Young Singers Singing Contest of CCTV (China Central Television), some audience members recognized some contestants and even some judges were students of Jin Tielin (Nanjing Ribao 2001). Currently, as those musicians and vocal teachers age, their influence on the music industry is declining, but their social connections still could be helpful for musicians trying to become party stars. The importance of having a good teacher was emphasized in interviews with media people.

Annie (entertainment journalist) ${ }^{7}$ :

...For instance, if he becomes a student of those famous composers or musical teachers, he might have songs written for himself and be recommended to (others). ....And he could... have chances to appear on CCTV or other television stations... singing or performing at those galas. Then, (he) would become well-known gradually....

In addition to colleges providing vocal training and nurturing social relationships for party stars, PLA song and dance troupes provide their prospective party stars first-class platforms to promote themselves and their performances. These troupes have resources to let singers appear on CCTV, on television galas, or at state-sponsored concerts (Jones 1992). At these galas, or events, they always have to sing patriotic songs or revolutionary songs, which link their own images closely to the party ideology, such as Song Zuying's well-known song "Love My China” (aiwo zhonghua), which applauds the harmony between diverse ethnicities and their love for greater China. Other benefits for these musicians include musical rewards in official singing contests, economic revenues from album sales and commercial shows (Fung 2009). In addition to vocal and emotional proficiency in singing patriotic songs and state-sanctioned songs, sometimes political timing might also influence their stardom, such as when Dong Wenhua sang "The Bright Color
With Blood (xueran de fengcai)" in the 1980s ${ }^{8}$.

Song Zuying is a good example of this production process. Song Zuying first became a professional singer with a non-military song and dance troupe in Hunan Province (Chang 2011). Then, after vocal training at the China Conservatory under Jin Tielin, she entered the PLA Navy Political Department Song and Dance Troupe (haizheng gewutuan) in 1991 and remained there, now as the associate head of the troupe (Chang 2011).

Each party star's stardom represents not only their personal accomplishments in music, but also the success of state power, including the success of media power. There is little audience power involved in the production of party stars.

\section{THE PRODUCTION OF COMMERCIALIZED STARS}

The main force behind the production of commercialized stars is always that of agencies or music-recording companies. Usually, the talents of would-be commercialized stars are discovered by producers or musicians (Dyer 1998), with whom the prospective stars then sign contracts. Then, with professional help from the agencies with whom they have signed contracts, the musicians release albums and are promoted through advertising, music charts, and concerts, accumulating fame step by step. This process is addressed by one entertainment journalist, Annie:

...Take Sun Nan $^{9}$ and Na Ying ${ }^{10}$ as examples: They both found good teachers at the beginning of their career development because their teachers found their potential-potential for future development-in their performances. Or some singers singing in bars and their talents are discovered by musicians or producers who happened to have fun there. Then, they were discovered in this way. It seems Yang Kun ${ }^{11}$, for instance, sang in bars at the beginning of his career, and so did Sha Baoliang ${ }^{12}$. Then, they were dug out. There are still many ways for singers to stand out. 
In order to attain economic success, the promotion and advertising of potential stars are completely commercial. In-depth interviews show how the new talents of recording companies are promoted through media exposure.

Sara (director):

...(The promotion of new talents) usually, undoubtedly, includes advertising, appearances, and tabloids. The public relation executive of the company must write news for them, about releasing albums, or co-operating with someone bla bla, drawing media attention. That is all. And casting in a movie, television drama, releasing an album, etc., belong to promotion as well.

One of the earliest commercialized stars in mainland China, Yang Yuying, signed with an agency and received a recording contract with the Guangdong New Times Recording Company (guangdong xinshidai yingxin gongsi), the first private-run recording company to import the agency system of artists from Hong Kong to mainland China in 1990 (Huang 2009). The company designed her image and musical style according to the demands of the music market (Wu 2003), and invested in the production of her album, advertising and promoting for her on CCTV (Huang 2009). Thus, Yang's albums were sold one million copies and she became well-known for her "sweet songs".

Commercialized stars are successful commercial products for recording companies and agencies and are under less ideological control by the party state. As Couldry (2000) mentions, they are products of media power. The production process of these stars is close to audience and there is little audience power involved in it.

\section{THE PRODUCTION OF LI YUCHUN'S STARDOM AND AUDIENCE POWER}

The main forces producing talent show stars are television stations, audiences, and agencies who cooperate with the television stations mentioned above. For instance, the main producers of Li Yuchun have been HNTV, its audience, and EE-Media, HNTV's subsidiary agency.

Talent shows let media power integrate with audience power by group audition such as the sea-selection in SGV (Cui and Lee 2010). The director, Sara, interviewed by the author emphasized the openness of $S G V, H B V$, and $H G V$, for ordinary people at the beginning of the show:

Well, what the sea-selection wants actually is what you look like, usually. Then, it can let most people participate in the greatest degree. When those ordinary people really have fun with their performance in the sea-selection (giggling), actually the audience has fun too. And, it is good for... the "diversity", as my boss said (giggling lightly)...

After this process, contestants received gradual training and the grooming of their singing, their style, and their image in talent shows (open to audience sometimes), which showed the creation of media power step by step (Cui and Lee 2010). The director described the importance of this grooming process for the contestants of $H B V$ and $H G V$.

Sara said:

... (They) ${ }^{13}$ had to take lessons every week. Uh... for instance... it was really a mixture, for instance, ... uh... lessons of acting, from Yu Entai ${ }^{14}$ (giggling), and... vocal training, um... which would be checked every week in the show as a quiz in classroom. Moreover, one Korean stylist helped them hydrate their skins, and there was a dancing teacher to offer guides for their fitness training...

In addition to the media which produce the show, another main force behind the production of talent-show stars is the audience, which is involved via text voting. The director of HNTV also confirmed it in Li Yuchun's case.

Sara (director):

What (Li Yuchun) represents is... our choices. It means we choose stars by ourselves. We really had fun in this thing: 
sending SMS (Short Messaging Service) votes, millions of votes, and choosing our own star...

One entertainment journalist thought audience power was the most distinguishing element of such talent shows, including $S G V, H G V$, and $H B V$.

Annie (entertainment journalist):

... because I am watching her all the time and find she has become mature gradually, making improvement. And to what degree she can continue her career depends on my choices. As a fan, I could decide her fate. Then, I vote for her, calling for votes, just because (I) decide where she can go in this road. That is... she... why they were so famous at that time. They mean a lot for the star system in mainland China and are labels for a generation, or persons with the characteristics of the generation.

With the end of talent shows, the production of talent show stars has transferred into the hands of agency companies. For example, after $S G V$, Li Yuchun signed with EE-Media. The company then created a recording studio to design and manage her music career and organized many big television concerts and movies for her, which improved her fame.

Susan (entertainment journalist):

...In addition to this, after she (Li Yuchun) signed with EE-Media, the company did a series of actions for her, including the design of her image, the grooming, her clothes and style, music style, songs and lyrics written for her for the album released by Taihe Rhe Music Co. Ltd., a recording company that signed her $\mathrm{at}^{15} \ldots$ and the high level commercial shows she attended, some great galas she appeared on, songs for charity works, those... those movies, such as Dark October, for which she was cast and nominated as best new talent. All of these, considering every aspect, all dimensions of the production of her stardom played important roles in the process of her becoming a star.

The images of talent-show stars are diverse and represent the attitudes of the young audience. For example, Li Yuchun's image combines the authentic attitude of the young generation with the sexuality of a "tomboy". This partly results from the financial demands of television stations and agencies, which are relatively independent of the demands of the state.

Meanwhile, Li Yuchun's stardom was a product of reproducing media power (Cui and Lee 2010), represented by manipulations of media institution as HNTV and EE-media, and audience power represented by audience text voting. There did audience power involved in the production of $\mathrm{Li}$ Yuchun's stardom and other stars from SGV.

\section{CONCLUSIONS}

Data shows that there is virtually no audience power involved in the production of party stars and commercialized stars, but audience power, produced by text voting, is integrated into the production of talent-show stars like Li Yuchun. Nevertheless, it is still too early to recognize audience power as the biggest motive behind the production of talent-show stars, because there is still media power produced in talent shows, such as the closeness of media/ordinary boundary in the final episode of $S G V$ and because of the grooming process (Cui and Lee 2010), the promotion and investment of agencies since the demise of talent shows.

Furthermore, although state power was weaker in the production of Li Yuchun's stardom than it did in production of party stars, it never completely disappeared in her rise to popularity. State influence is conveyed by the licensing regulations and restrictions on talent shows that were enforced by the government. Particularly after the success of $S G V$ in 2005, state power strengthened its control in star production by issuing many restrictions on talent shows during the September of 2007, including the cancelation of voting (Xinhua Net 2007), expanding and producing talent shows on CCTV, such as China's Good Song (zhongguo haogequ) ${ }^{16}$, by cooperating with foreign production companies. Even though these activities suggest that state power is negotiating with media 
power, it excludes the involvement of audience power from the creation of stars, and it shows that state power would not permit any loosening of its control on cultural production, even if it was just regarding a television show. Meanwhile, this also made $\mathrm{Li}$ Yuchun and other talent-show stars that were introduced before September, 2007, the last sample created by media power and audience power. Whether the negotiation of media power and the involvement of audience power in the production of talent-show stars like $\mathrm{Li}$ Yuchun will further influence the audience consumption of talent-show stars still is open for exploration.

\section{Funding}

This study was supported by the Social Science Doctoral Funds in Chongqing (2014BS126).

\section{Notes}

1. The term "party star" is inspired by terms used in other works on Chinese media under the control of the party-state (Lee, He, and Huang 2007; Tong and Sparks 2009).

2. HNTV was one of the top-ten channels in six of 10 central cities where viewing data was collected by CVSC-Sofres Media (CSM) according to data publicly released in 2009. See details at its official website: http://www.csm. com.cn/index.php/knowledge/market/type/1.html.

3. The Voice of China is the legal Chinese version of the Voice of Holland, which is a talent show designed to promote Chinese pop star. It began to air on Zhejiang Satellite Television Station (ZJTV) from 2012 and is produced by the Pal Edward Culture and Communication Company controlled by News Cooperation.

4. A singer who became well-known for singing "The Full Moon" (shiwu de yueliang) and "The Bright Color of Blood" (xueran de fengcai).

5. See its official website at: http://www.81art.com/.

6. See its official website at: http://www.ccmusic. edu.cn/xygk/xyjj/.

7. For the privacy of interviewees, the interviewees' real names are replaced with English names randomly picked by the author.

8. "The Bright Color of Blood" (xueran de fengcai) praises the sacrifices made by soldiers for the country. When Dong sang these songs (1984), China was at war with Vietnam (the third period of the war with Vietnam). Hence, Dong and her songs became immensely popular in China during this period.

9. A well-known male pop star in mainland China.

10. A female pop star in mainland China.

11. A male pop star is well-known because of the song "It Doesn't Matter (wusuowei)”.

12. A male pop star that was famous because of the song "Fragrance (anxiang)".

13. She means the contestants of $H B V$ in 2007 and of $H G V$ in 2009.

14. A popular comedy actor in mainland China.

15. After $S G V$ in 2005, Li Yuchun signed an agency contract with EE-Media and a recording contract with Taihe Rhe Music Co. Ltd., because EE-Media did not have experience in the recording business. In 2010, she renewed her agency contract with EE-Media and signed a singing contract with EE-Media as well.

16. China's Good Song (zhongguo haogequ) is an original talent show designed to promote Chinese pop music that began to air on CCTV in 2014 and that is produced by CCTV and the Pal Edward Culture and Communication Company controlled by News Cooperation.

\section{References}

Andrejevic, M. 2004. Reality TV: The Work of Being Watched. Lanham, MD: Rowman \& Littlefield Publishers.

Ball-Rokeach, S. J. and M. L. DeFleur. 1976. "A Dependency Model of Mass-Media Effects.” Communication Research 3(1):3-21.

Baranovitch, N. 2003. China's New Voices: Popular Music, Ethnicity, Gender, and Politics, 1978-1997. Berkeley, CA: University of California Press.

Bell-Jordan, K. E. 2008. "Black. White. And a Survivor of the Real World: Constructions of Race on Reality TV.” Critical Studies in Media Communication 25(4):353-372.

Bourdieu, P. 1991. Language and Symbolic Power. Edited by J. B. Thompson, translated by G. Raymond and M. Adamson. Cambridge, MA: Polity Press.

Chang, S. 2011. "Song Zuhying Chonghyou xiangxi yeli gucheng, huiyi 30 nian qian jingli” (Song Zuying Visit the Old City Yeli in Xiangxi, Refresh Her 30 Years' Memory). China News Service, June 25, p. 8B.

Chen, B. J. 2011. "Lun meisheng, minzhu, tongsu sanzhong changfa de tedian” (Discussions on Characteristics of Bel Canto, Folk and Tongsu Singing Styles). Beifang Yinyue 3:19.

Chen, X. Y. 2007. "Dianying mingxing, shijue zhengzhi yu xiaofei wenhua” (Film Stars, Visual Politics and Consumer 
Culture: The Chinese Film-Stars in the Context of Contemporary Urban China). Wenyi Yanjiu 1:12-18.

Coudlry, N. and J. Curran. 2003. "The Paradox of Media Power.” Pp. 3-17 in Contesting Media Power: Alternative Media in a Networked World, edited by N. Couldry and J. Curran. Lanham, MD: Rowman \& Littlefield.

Couldry, N. 2000. The Place of Media Power: Pilgrims and Witnesses of the Media Age. London; New York: Routledge.

— 2003. "Beyond the Hall of Mirrors? Some Theoretical Reflections on the Global Contestation of Media Power." Pp. 39-54 in Contesting Media Power: Alternative Media in a Networked World, edited by N. Couldry and J. Curran. Lanham, MD: Rowman \& Littlefield.

Couldry, N. and T. Markham. 2008. "Troubled Closeness or Satisfied Distance? Researching Media Consumption and Public Orientation.” Media, Culture \& Society 30(1):5-21.

Cui, L. and F. L. F. Lee. 2010. "Becoming Extra-Ordinary: Negotiation of Media Power in the Case of Super Girls' Voice in China." Popular Communication: The International Journal of Media and Culture 8(4):256-272.

Dahebao. 2002. “'Tong yi shouge’ zaoyu lengre liangzhang lian” ("The Same Song” Receives Mixed Responses). April 30, p. 18.

Darling-Wolf, F. 2004. "Virtually Multicultural: Trans-Asian Identity and Gender in an International Fan Community of a Japanese Star.” New Media Society 6(4):507-528.

Dyer, R. 1998. Stars. London: BFI Pub.

Ellis, J. 1992. Visible Fictions: Cinema, Television, Video. London; New York: Routledge.

Fairchild, C. 2007. "Building the Authentic Celebrity: The 'Idol' Phenomenon in the Attention Economy." Popular Music and Society 30(3):355-375.

Fan, L. 2005. “'Chaoji Nusheng' de diyilun shouge” (The First Round of Harvest of Super Girls' Voice). Dangdai Jingliren 11:35-36.

Feilitzen, C. V. 1994. "Media Violence-Research Perspectives in the 1980s.” Pp. 147-170 in Mass Communication Research: On Problems and Policies: The Art of Asking the Right Questions: In Honor of James D. Halloran Norwood, edited by C. J. Hamelink and O. Linne. NJ: Ablex Pub. Corp.

Fiske, J. 1992. “The Cultural Economy of Fandom.” Pp. 30-50 in The Adoring Audience: Fan Culture and Popular Media, edited by L. A. Lewis. London; New York, NY: Routledge.

Forbes (China). 2010. The Forbes List for Chinese Celebrities 2010. Retrieved November 17, 2014 (http://www. forbeschina.com/list/358).

Fung, A. Y. H. 2009. "Fandom, Youth and Consumption in China.” European Journal of Cultural Studies 12(3):285-303.
Gamson, J. 1994. Claims to Fame: Celebrity in Contemporary America. University of California Press, Berkeley.

—. 2001. "The Assembly Line of Greatness: Celebrity in Twentieth-Century America.” Pp. 259-282 in Popular Culture: Production and Consumption, edited by C. L. Harrington and D. D. Bielby. Malden, MA, Oxford: Blackwell Publishers.

Garnham, N. 1990. Capitalism and Communication: Global Culture and the Economics of Information. London: Sage.

Gerberner, G. 1994. "The Politics of Media Violence: Some Reflections.” Pp. 133-145 in Mass Communication Research: On Problems and Policies: The Art of Asking the Right Questions: In Honor of James D. Halloran Norwood, edited by C. J. Hamelink and O. Linne. NJ: Ablex Pub. Corp.

Gitlin, T. 1980. The Whole World Is Watching. Berkeley: University of California Press.

Grossberg, L. 1992. "Is There a Fan in the House?: The Affective Sensibility of Fandom.” Pp. 50-69 in The Adoring Audience: Fan Culture and Popular Media, edited by L. A. Lewis. London; New York, NY: Routledge.

Hall, S. 1988. "The Rediscovery of 'Ideology': Return of the Repressed in Media Studies.” Pp. 56-90 in Culture, Society and the Media, edited by M. Gurevitch, T. Bennett, J. Curran, and J. Woollacott. London; New York, NY: Routledge.

Hartley, J. 2004. “'Kiss Me Kat': Shakespeare, Big Brothers, and the Taming of the Self.” Pp. 303-323 in Reality TV: Remaking Television Culture, edited by L. Ouellette and S. Murray. New York, NY: New York University Press.

Holmes, S. 2004. “'Reality Goes Pop!': Reality TV, Popular Music, and Narratives of Stardom in Pop Idol.” Television \& New Media 5(2):147-172.

Hou, H. F. 2005. "Dianshi xuanxiu jiemu xianqi pingmin zaoxing yundong” (Talent Shows Swirl a Trend of Making Ordinary Stars). Shiting Zhongheng 5:22-23.

Huang, R. H. 2009. “'Xinshidai' jijiang luomu, ting qianlaoban Wujianbang jianggu, Yang Yuying, Mao Ning zheyang congzhongguo zouhong quanguo” ('New Times' Is Closing, Listening the History From Former CEO Wujianbang, Yang Yuying and Mao Ning Became Famous From Guangdong Like This). Nanfang Dushibao, March 11, p. B04.

Jiang, W. J. and S. J. Wang. 2009. "Hunan Weishi liangzhang pai: Liwan Long Danni” (Two Cards in the Hands of Hunan Satellite TV: Nice Try for Long Danni). Xinwen Tiandi 12:27-28.

Jin, Z. 2006. "Cong Chaoji Nvsheng de ronghe chuanbo kan yule jingji de chanye zhilu:dui hunan yule pindao zongjian zhanghuali, tianyu gongsi laozong wangpeng deng de fangtan” (Review the Entertainment Business From the 
Integrated Communication of Super Girls' Voice: Interviews With the Chief Inspector of Entertainment Channel of HNTV, Zhang Huali and the Chairman of Board of EE-Media, Wang Peng, etc.). Shitingjie 1:5-12.

Jin, Z. J. 2002. "Guangtian huari xia de liuxing: Qinli Zhongguo liuxing inure” (The Popular Under Sunshine: Experiencing the Chinese Popular Music). Beijing: People's Music Publishing House.

Jones, A. F. 1992. Like a Knife: Ideology and Genre in Contemporary Chinese Popular Music. Ithaca, NY: Cornell University East Asia Program.

- 1994. "The Politics of Popular Music in Post-Tiananmen China.” Pp. 148-165 in Popular Protest and Political Culture in Modern China, 2nd ed., edited by J. N. Wasserstrom and E. J. Perry. Boulder: Westview Press.

Jones, J. M. 2003. "Show Your Real Face: A Fan Study of the UK Big Brothers Transmissions (2000, 2001, 2002). Investigating the Boundaries Between Notions of Consumers and Producers of Factual Television." New Media \& Society 5(3):400-421.

Katz, E. and P. F. Lazarsfeld. 1955. Personal Influence: The Part Played by People in the Flow of Mass Communication. New York, NY: Free Press.

Keane, M., A. Y. H. Fung, and A. Moran. 2007. New Television, Globalization, and the East Asian Cultural Imagination. Hong Kong: Hong Kong University Press.

Lee, C. C., Z. He, and Y. Huang. 2007. "Party-Market Corporatism, Clientelism, and Media in Shanghai." The Harvard International Journal of Press/Politics 12(3):21-42.

Litter, J. 2004. "Making Fame Ordinary: Intimacy, Reflexivity, and 'Keep It Real'.” Mediactive: Ideas/Knowledge/Culture 2:8-25.

Magder, T. 2004. "Television 2.0: The Business of American Television in Transition.” Pp. 141-164 in Reality TV: Remaking Television Culture, edited by L. Ouellette and S. Murray. New York, NY: New York University Press.

Marshall, P. D. 1997. Celebrity and Power: Fame in Contemporary Culture. Minneapolis, MN: University of Minnesota Press.

McCombs, M. E. and D. L. Shaw. 1972. "The Agenda-Setting Function of Mass Media.” Public Opinion Quarterly 36(2):176-187.

Meng, B. J. 2009. "Who Needs Democracy If We Can Pick Our Favorite Girl? Super Girl as Media Spectacle.” Chinese Journal of Communication 2(3):257-272.

Minichiello, V., R. Aron, E. Timewell, and L. Alexander. 1995. In-Depth Interviewing: Principles, Techniques, Analysis. 2nd ed. Melbourne: Longman.

Murdock, G. 1988. "Large Corporations and the Control of the Communications Industries.” Pp. 118-150 in Culture,
Society and the Media, edited by M. Gurevitch, T. Bennett, J. Curran, and J. Woollacott. London; New York, NY: Routledge.

Murdock, G. and P. Golding. 1974. "For a Political Economy of the Mass Media.” Pp. 205-234 in The Socialist Register 1973, edited by R. Miliband and J. Saville. London: Merlin Press.

Nanjing Ribao. 2001. "Yangshi geshou dadai meizhong buzu" (Shortcomings in the National Young Singers Contest of CCTV). May 9, p. 4a.

Netease. 2014. "Chunwan jiemudan baoguang, Huachenyu xieshou Liqi Hangchunwan" (Exposure of the List of Spring Festival Galas: Hua Chenyu and Liqi Will Perform Together at the Gala). Retrieved August 22, 2014 (http://ent.163.com/14/0119/09/9IUNNO7S00031GVS.htm l).

Pullen, K. 2004. "Everybody's Gotta Love Somebody, Sometime: Online Fan Community.” Pp. 80-91 in Web Studies, 2nd ed., edited by D. Gauntlett and R. Horsley. London: Arnold; New York: Oxford University Press.

Raphael, C. 2004. "The Political Economy Origins of Reality-TV.” Pp. 119-137 in Reality TV: Remaking Television Culture, edited by L. Ouellette and S. Murray. New York, NY: New York University Press.

Reijnders, S. L., G. Rooijakkers, and L. V. Zoonen. 2007. "Community Spirit and Competition in Idols-Ritual Meanings of a TV Talent Quest.” European Journal of Communication 22(3):275-292.

Rojek, C. 2001. Celebrity. London: Reaktio Books.

Ruddock, A. 2001. "Media: Hello! Have Redtops Said Goodbye to Politics?: Alan Ruddock Argues That the Tabloids' Slide Into Infotainment Has Serious Implications for Broadsheets.” Observer, August 26, p. 7.

Saich, T. 1994. "Discos and Dictatorship: Party-State and Society Relations in the People's Republic of China.” Pp. 246-267 in Popular Protest and Political Culture in Modern China, 2nd ed., edited by J. N. Wasserstrom and E. J. Perry. Boulder: Westview Press.

Sun, X. P. and A. L. Zhang. 2005. "Dianshi yule jiemu 'pingming zaoxing yundong' dui qingshaonian xinli de yingxiang” (The Psychological Impact of Television Entertainment Programs "Making Ordinary Stars" on the Teenagers). Shengping Shijie 8:4-6.

Tolson, A. 1996. Mediations: Text and Discourse in Media Studies. London; New York: Arnord.

Tong, J. R. and C. Sparks. 2009. "Investigative Journalism in China Today.” Journalism Studies 10(3):337-352.

Turner, G. 2004. Understanding Celebrity. London: SAGE.

—. 2006. "The Mass Production of Celebrity: 'Celetoids', Reality TV and the 'Demotic Turn'.” International Journal of Cultural Studies 9(2):153-165. 
Wang, X. J. 2009. “Jiema tianyu” (Decoding of EE-Media). Dangdai Jingliren 8:78-81.

Wu, F. S. 2003. "Yang Yuying tiange, 'Xinshidai' peichang 16 wan” (The Case of Yang Yuying's Sweet Songs, New Times Pay 160 Thousand for the Writer). Yinyue Tiandi 8:3-7.

Xinhua Net. 2007. "Guangdian Zongju jinzhi shengji shangxing pindao huangjin shijian shiduan bo хиаnхiu jiemu” (SARFT Issued Restrictions on Prohibiting Provincial Satellite Television Stations Launching Talent Shows in Prime Time). Retrieved August 22, 2014 (http://news.xinhuanet.com/legal/2007-09/21/content_6765 152.htm).

Zhang, H. Z., H. Xu, and Y. He. 2006. “'Chaonu’ xuanwo de chuanbo moshi yu chuanboxiaoguo yanjiu: yi Beijing diqu daxuesheng diaocha weili" (Communication Models and Effects on the Program of "Supergirl”). Guojin Xinwenjie
1:42-47.

Zhang, Q. 2007. "Xinmeijie huanjing zhongde shouzhong yanjiu" (Audience Studies in the Age of New Media: A Case Study of an Online Fan Community). Unpublished doctoral dissertation, Tshinghua University, Beijing, China.

Zhang, Y. J. and M. N. Hu. 2011. "Zhongguo dianying mingxing yanjiu” (Study of Film Stars in China). Dianying Yishu 336:105-108.

Zoonen, L. V. 2009. "Imagining the Fan Democracy." European Journal of Communication 19(1):39-52.

\section{Bio}

Li Cui, Ph.D., Southwest University, China; research fields: cultural studies, gender studies, health communication, and new media. 